Ethiopian Journal of Environmental Studies \& Management 9(4): 430 - 442, 2016.

ISSN:1998-0507

doi: http://dx.doi.org/10.4314/ejesm.v9i4.4

Submitted: February 02, 2016

Accepted: June 22, 2016

\title{
ANNUAL CROPPED AREA EXPANSION AND AGRICULTURAL PRODUCTION: IMPLICATIONS FOR ENVIRONMENTAL MANAGEMENT IN BENUE STATE, NIGERIA
}

\author{
*TERDO0, F., ${ }^{1}$ GYANG, T. ${ }^{2}$ AND IORLAMEN, T.R. ${ }^{3}$ \\ ${ }^{1}$ Department of Geography and Regional Planning, Federal University Dutsin-Ma, Katsina \\ State, Nigeria \\ ${ }^{2}$ Department of Agricultural Economics and Agribusiness, Federal University Dutsin-Ma, \\ Katsina State, Nigeria \\ ${ }^{3}$ Department of Agricultural Economics, University of Agriculture, Makurdi, Benue State, \\ Nigeria
}

\begin{abstract}
This paper assesses the relationship between annual cropped area expansion and crop output and discusses the implication of such a relationship for environmental management in Benue State, Nigeria. The study was carried out using agricultural production survey (APS) data of five selected crops, namely: rice, sorghum, maize, yam and cassava for over two decades (i.e. 1989 to 2011), obtained at Benue State Agriculture and Rural Development Authority (BNARDA). The data was subjected to correlation analysis. The results reveal a considerable annual increase of varying extent over time and space for both annual output and area expansion of each of the five selected crops in Benue State on one hand. While on the other, the analyses reveal the existence of very high positive correlations between area cropped and output for four crops. However, a very weak negative relationship is revealed for area cropped and sorghum output. The study suggests improving productivity through sustainable agricultural intensification may significantly reduce the rate of conversion of arable lands to cropped area and equally help manage the environment in the state.
\end{abstract}

Key Words: Agricultural Intensification, Crop output, Environment, Benue State, Nigeria

\section{Introduction}

One of the major challenges facing the world today, especially those in Africa, is food security. Therefore, it has become the main focus of many African countries to attain self-sufficiency in food production to ensure food security. In the last three decades, intensification has been largely responsible for averting a shortfall in food supply in many countries. There is ample evidence to suggest that food security in many parts of the world has been achieved through agriculture intensification (Akudugu et al., 2013; FAO, 2010; Phalan et al., 2013; Pretty et al., 2010; Rudel et al., 2009; Saeed, 2000).

*Corresponding Author: Terdoo, F. 
Annual Cropped Area Expansion and Agricultural Production................TERDO0 et al.

The goal of agricultural intensification has been to produce enough food to meet the growing demand for food and improve human well-being. For this reasons, agriculture intensification has been on the policy agenda of many countries, organizations and institutions of the world (Dawson et al., 2016; Josephson et al., 2014; NinPratt and McBride, 2014; Sitko and Jayne, 2014). While agricultural intensification in the developed world has been dominated by large scale (commercial) farmers using improved seed varieties and irrigation agriculture, in the developing world small smallholder (subsistence) farmers dominate (Kassie et al., 2015; Nin-Pratt and McBride, 2014; The Montpellier Panel, 2013).

In the developing countries, low level technology usage, lack of basic inputs and incentives, and the challenge of global environmental change has limited technological inputs to advance agricultural intensification. Rather, the dominant practice of agricultural intensification has been annually expanding cropping areas (Grassini et al., 2013; Rudel et al., 2009; Saeed, 2000) . This practice is often supported by national and regional governments without adequate attention to the possible consequences especially in the face of shifting cultivation and bush fallow, which are major system of agriculture practiced across Africa. The renewed interests in the developing world for expansion in annual area under cultivation for crops, which is largely driven by farmer's response to the worldwide concern to provide food to feed the rising population of hungry people in the world, improve family income and standard of living.
Agricultural intensification, theoretically, sets in motion two countervailing forces, namely: the one that increases area under cultivation and the one that reduces cultivated areas (Rudel et al., 2009). Both of these aspects of agricultural intensification aim at increasing crop yield and improving the livelihood of farmers generally. However, they are not without their attending challenges. Apart from putting pressure on new lands, every farming season, agricultural intensification put pressure on farmers as well (Dawson et al., 2016). For example, farmers are often faced with the challenge of clearing new farm lands every farming season, hence increasing their spending on purchase of new farming implements such as cutlass, machetes, and axes, used for clearing new farm lands. Since majority of the farmers cannot afford the cost of hiring a tractor, alternatively resort to hiring more people and hence pay more labour costs.

Furthermore, annual expansion in acreage by farmers in turn, leads to additional spending on seedlings, herbicides, insecticides, and other labour costs on one hand. While on the other hand, the practice often leads to the challenge of continuous conversion of other land uses such as residential, urban, forestry, and industrial to agricultural lands with numerous environmental consequences such as land degradation, deforestation, soil erosion and desertification which exacerbate global environmental change (GEC) processes (Dawson et al., 2016; Sitko and Jayne, 2014; The Montpellier Panel, 2013).

Agriculture intensification, in any of the two forms discussed above, shows the degree of governance in the agricultural sector of any state and is of prime importance to investors, planners and 
environmental managers (Mandemaker et al., 2011). In the developed countries for example, where advances in agronomic practices and technology has led to high level of governance in the agricultural sector, little land and more inputs and machinaries are being used in carry out farming activities (Dawson et al., 2016; Mandemaker et al., 2011; Sitko and Jayne, 2014). However, the opposite is the case in most African countries, as annual expansion in cropping land are now dominant, resulting in agricultural land scarcity and conflicts. Hence, the scope for a further increase in cropping land is becoming limited.

Continued expansion of agricultural lands may begin to slow in the coming years and future prospects for increasing agricultural output and ensuring food security been threatened. In the face of impending land shortage and possible impact on food production, it is high time governments of African countries begin to device policies to address the situation. While some existing studies have attributed crop output in sub-Saharan Africa to area expansion (Akudugu et al., 2013; Mandemaker et al., 2011), it has been no sufficient evidence to confirm if this situation is true for various crops and various eco regions across Africa. As such, the start point for developing adequate policies is to solidify the evidence base of the relationship between land area and crop yield.

Therefore, using five selected crops cultivated by majority farmers in Benue State, Nigeria, this paper explores the relationship between annual cropped area expansion and crop output and discusses the implications such a relationship might have on the environment in the state. Emphasis is placed on cassava, yam, rice, sorghum and maize, because these crops account for the major food crops in Nigeria. The knowledge generated can inform policy-relevant understanding of the growth of the crop production subsector of the agriculture while also stimulate a healthy debate, leading to informing policies to reduce annual expansion of crop area, which often subjects farmers to additional stress and spending, and has led to conversion of lands meant for other uses to crop lands with numerous environmental challenges.

\section{Methodology \\ Study Area}

This study focuses on Benue state which is regarded as the "food basket of Nigeria". Benue State lies between latitudes $6^{0} 25^{\prime} \mathrm{N}$ and $8^{0} 8^{\prime} \mathrm{N}$ of the equator and between longitudes $7^{0} 47^{\prime} \mathrm{E}$ and $10^{\circ} 00^{\prime} \mathrm{E}$ of the Greenwich meridian (Figure 1). The state has a total land area of 30,800 sq. km (National Bureau of Statistics, 2012). The total population is estimated to be 4,253,641 (National Bureau of Statistics, 2012). According to the Koppen Classification Scheme, Benue state falls within the Aw Climate-a Tropical Climate with two distinctive wet and dry seasons. The State generally has about 8-10 months of rainfall. Temperatures are constantly high throughout the year, with average temperatures ranging from $23^{\circ} \mathrm{C}-32^{\circ} \mathrm{C}$. The climate of the State accommodates a wide range of agricultural production such as fruit crops, grain crops, and tuber crops. While the vegetation of Benue State is typically that of the southern Guinea Savannah biome, characterized by sparse grasses and numerous species of scattered trees. Agriculture forms the thrust of the Benue State economy, engaging well over $75 \%$ of the working population. 


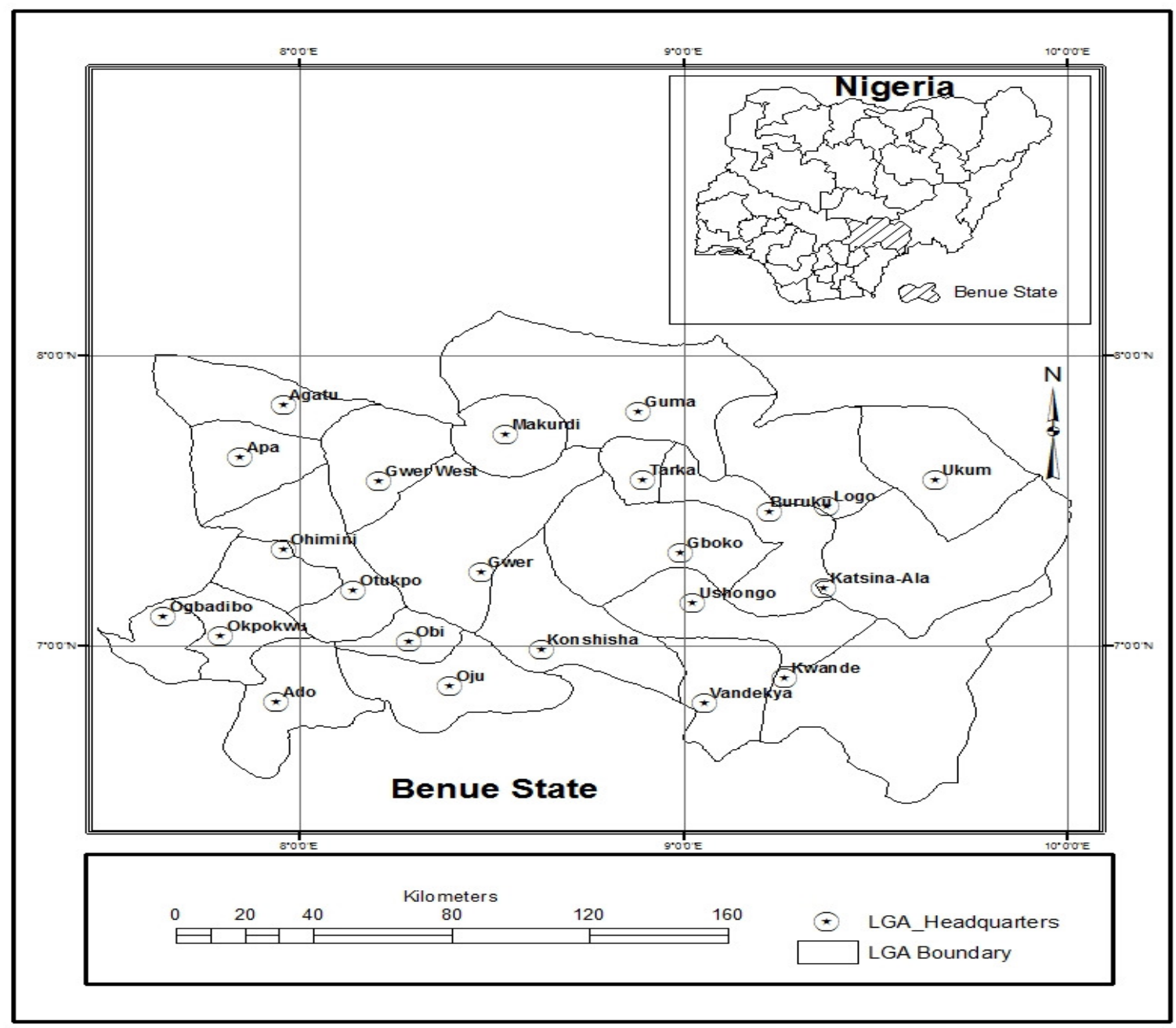

Figure 1: Map of Study the Area

\section{Data Collection}

To be able to assess the relationship between annual cropped area expansion and annual output of some selected crops in Benue State, Nigeria, data for the parameters were collected from secondary sources. The data on annual cropped area expansion for the five selected crops, namely: cassava, yam, rice, sorghum and maize and annual output of each of the five crops, spanning the period of 1988-2011 was obtained from Benue State Agricultural
Development Authority (BNARDA), Makurdi. To build confidence in the data, it was validated with that from the report of the Agricultural Production Surveys (APS), 2010 of the National Programme for Agriculture and Food Security (NPAFS), Federal Ministry of Agriculture and Rural Development.

\section{Data Analysis}

The data was analyzed with the aid of a Statistical Package for Social Sciences (SPSS) version 16. Pearson correlation statistical tool was employed as the 
principal analytic tool to determine the relationship between the annual cropped area expansion and output of the selected crops, namely: cassava, yam, sorghum, maize and rice, the correlations were computed for all the variables. The independent variables $(\mathrm{x})$ are the annual cropped area expansion for each of the selected crops (cassava, yam, sorghum, maize and rice) while the dependent variables (y) are the output of each of the five selected crops (cassava, yam, sorghum, maize and rice).

\section{Results}

Table 1: Descriptive statistics of the output of the five selected crops in Benue State from $1989-2011$

\begin{tabular}{llll}
\hline Name of Crops & Total Output('(000mt) & Mean & Standard Deviation \\
\hline Cassava & 69501.66 & 3021.81 & 973.64 \\
Yam & 55066.61 & 2394.2 & 753.55 \\
Rice & 6252.76 & 271.86 & 39.32 \\
Sorghum & 4225.16 & 183.70 & 22.91 \\
Maize & 3170.54 & 137.85 & 34.92 \\
\hline
\end{tabular}

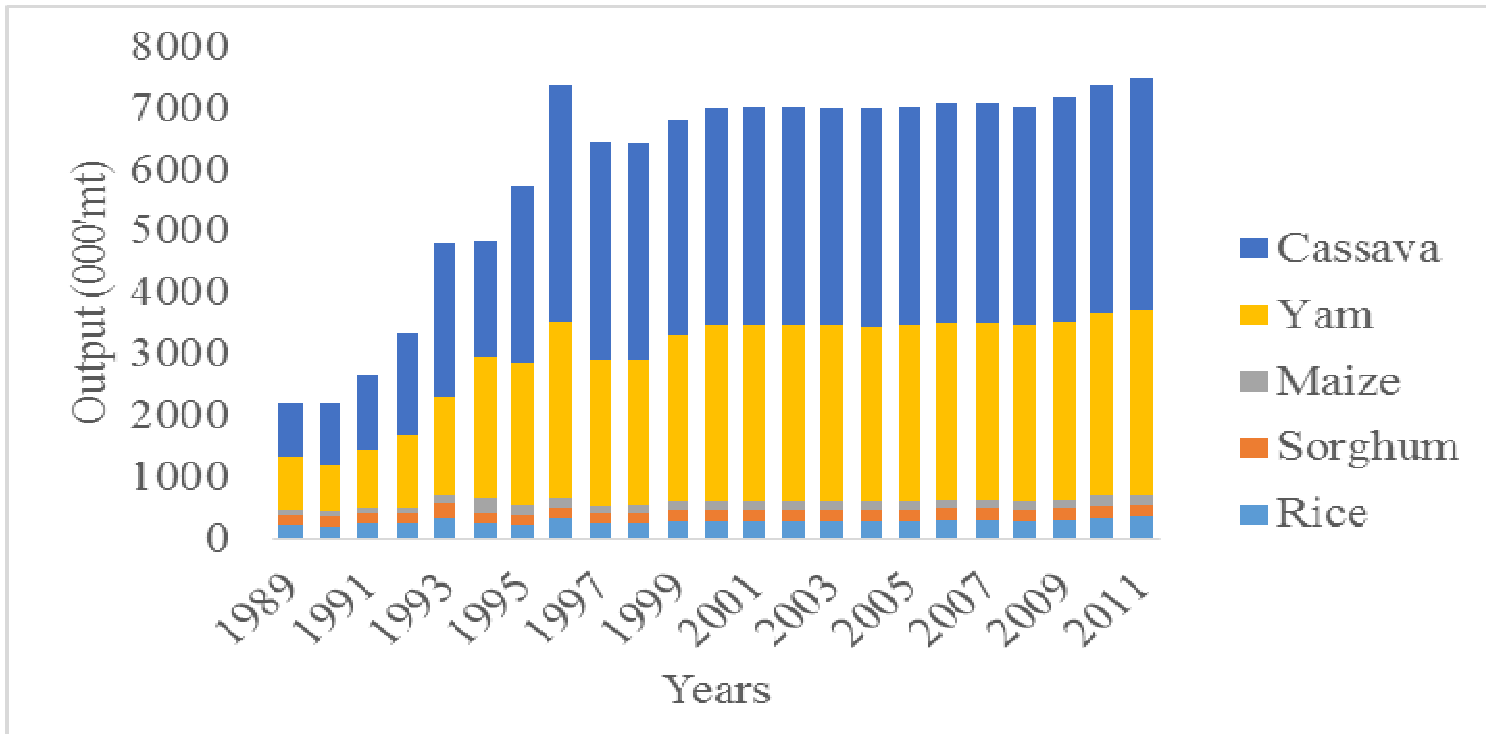

Figure 2: Trend in output of the five selected crops in Benue State between 1989 and 2011.

The data on the annual output for each of the five selected crops in Benue State from the period of 1989-2011 have been summarized and the results presented on table 1 . The result reveals that cassava crop has the highest output $(69501.66 \mathrm{mt})$ in the state. This is followed by yam crop $(55066.61 \mathrm{mt})$, then rice crop (6252.76mt), Sorghum crop (4225.16mt) and maize crop (3170.54mt) respectively. While the annual trend (Figure 1) reveals a steady increase in output of two crops i.e. cassava and yam out of the five selected crops from 1989 
and 2011. The highest output being recorded for cassava crop in 1996 while the lowest for maize was recorded in 1989 (Figure 2). Similarly, variability in the annual output for each of the five selected crops in the state was also investigated and the results presented on table 1 . The result reveals that cassava has the highest variability in output (973.64mt); it was followed by yam $(753.55 \mathrm{mt})$, rice and maize $(22.91 \mathrm{mt})$ in that order. Sorghum shows the lowest variability in annual output $(22.9 \mathrm{mt})$. This may be connected to the way it has been planted as an inter-crop by majority of farmers in the state.

Table 2: Descriptive Statistics of annual area cropped for the five selected crops in Benue State between 1989 and 2011

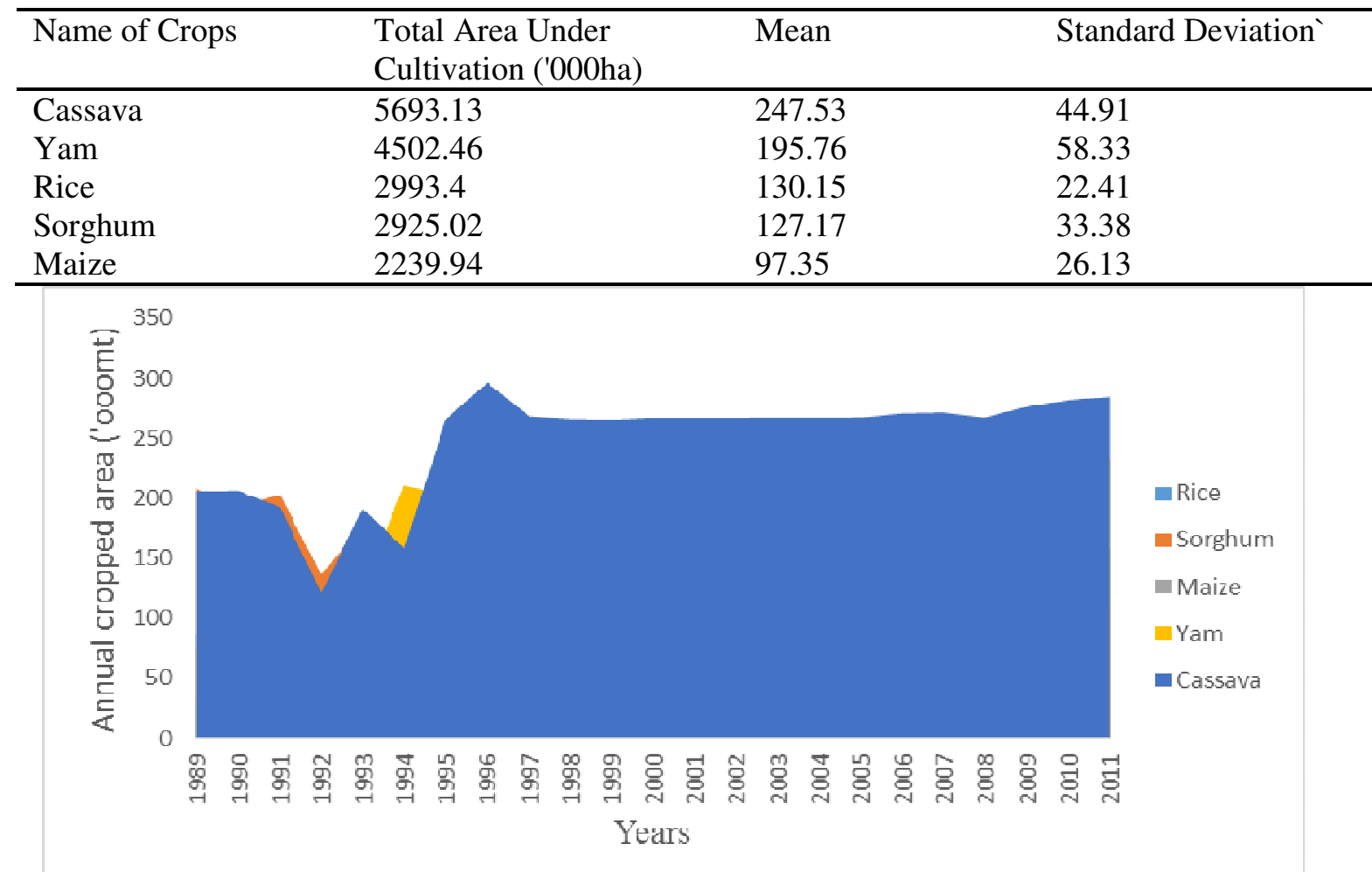

Figure 3. Annual area cropped for the five selected crops in Benue State from 1989 to 2011.

Aside from annual output, the results on the annual crop area for each of the five selected crops in Benue State from the period of 1989-2011 have been summarized and presented on table 2 (see also figure 2 for the trend). The result shows that the area crop for cassava (5693.13 ha) was the highest in the state. It was followed by yam (4502.46 ha), rice (2993.4 ha), sorghum (2925.02) and maize (2239.94 ha) in that order. Furthermore, the results (table 2) reveals the highest variability in the crop area of yam (58.33) while area for cassava crop (44.91) was next to yam, then sorghum crop (33.38) and maize (22.41) respectively. However, rice crop (22.41) shows the lowest variability in area crop for the period under review. 


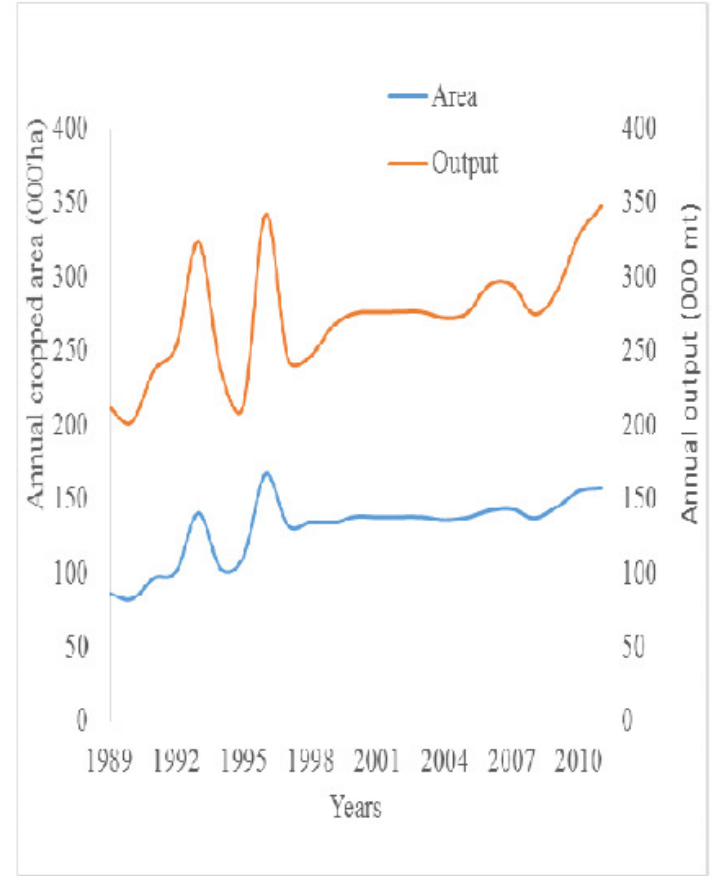

Figure 4: Relationship between annual cropped area for rice and output in Benue State (1989-2011)

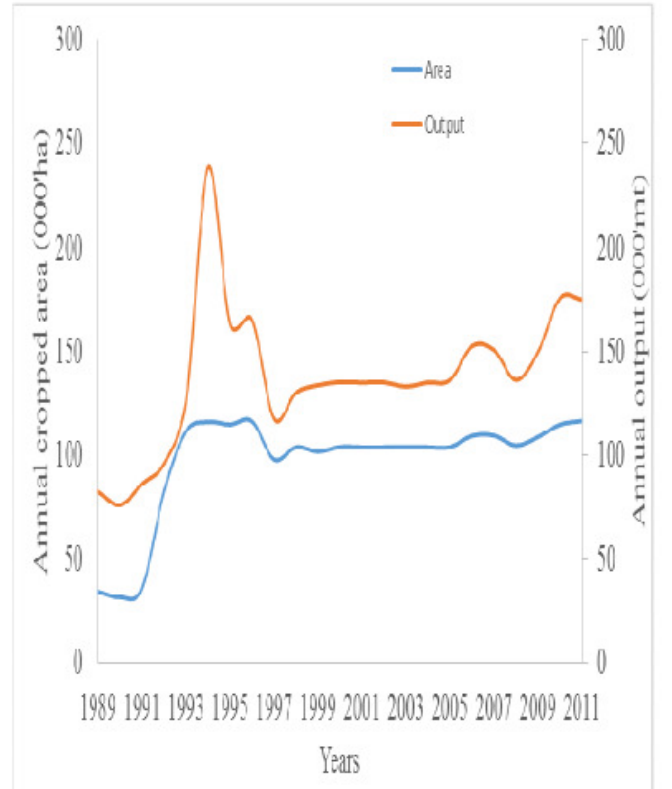

Figure 6: Relationship between annual cropped area for maize and output in Benue State (1989-2011)

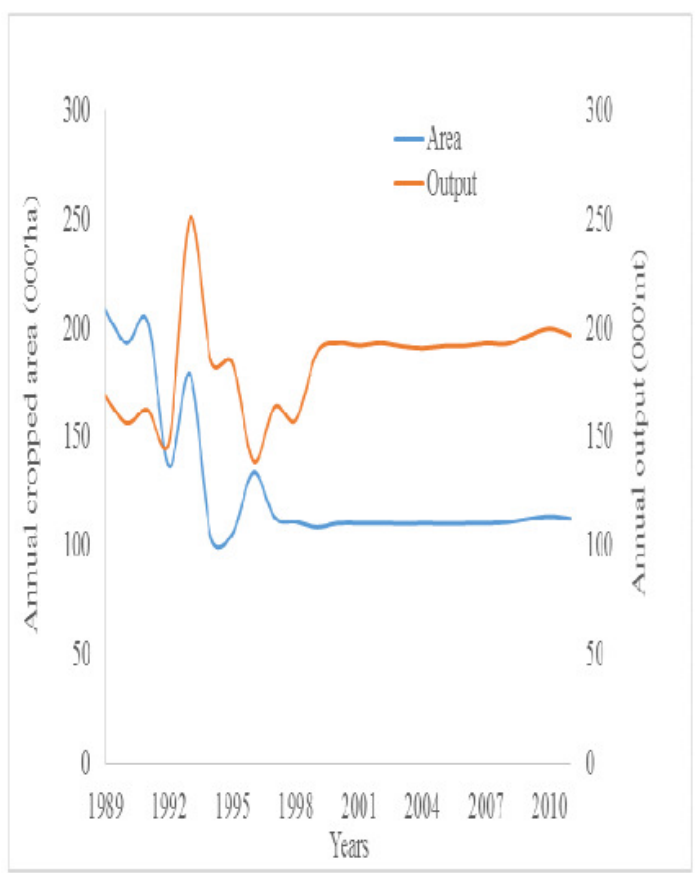

Figure 5: Relationship between annual cropped area for sorghum and output in Benue State (1989-2011)

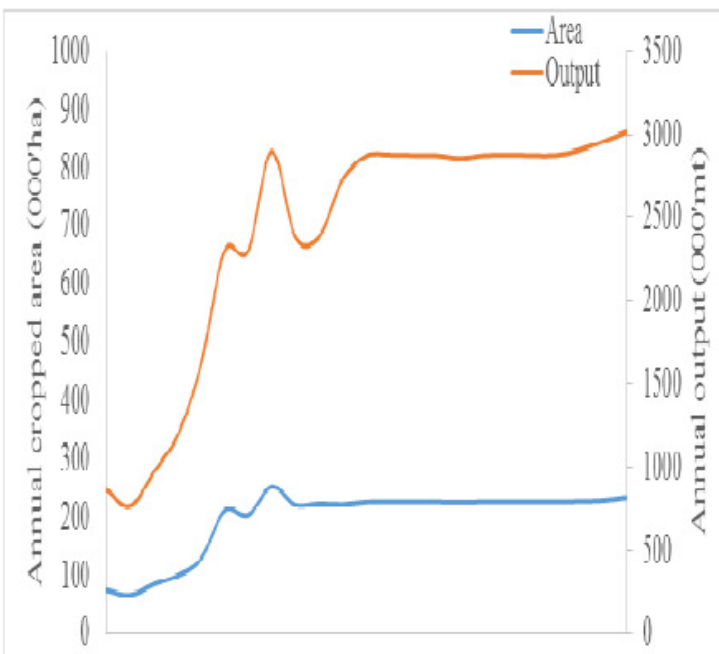

198919911993199519971999200120032005200720092011

$$
\text { Years }
$$

Figure 7: Relationship between annual cropped area for yam and output in Benue State (1989-2011) 


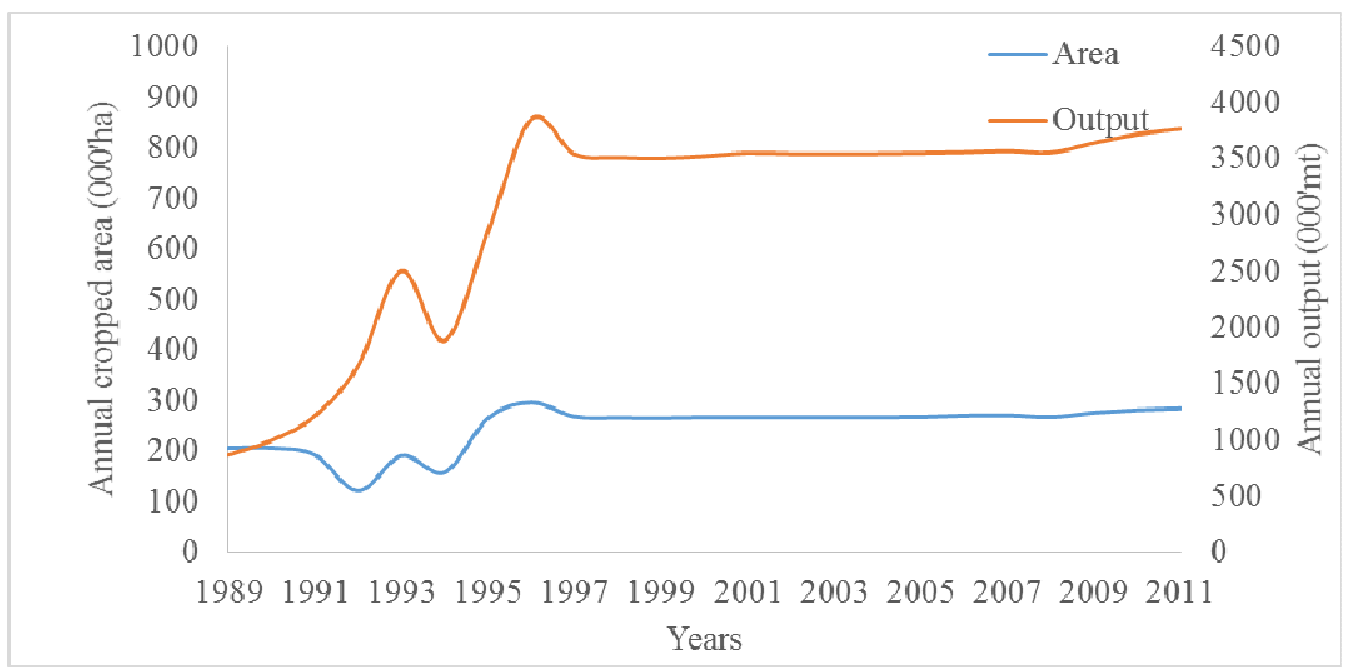

Figure 8: Relationship between annual cropped area for cassava and output in Benue State (1989-2011)

Table 4: Correlation of annual cropped area with output of selected crops in Benue State from1989-2011

\begin{tabular}{llll}
\hline Name of crops & Variables & $\mathrm{R}$ & Significance \\
\hline Yam & $\begin{array}{l}\text { Output } \\
\text { Area Cultivated } \\
\text { Rice }\end{array}$ & $0.978^{* *}$ & 0.000 \\
Cassava & $\begin{array}{l}\text { Area Cultivated } \\
\text { Output }\end{array}$ & $0.886^{* *}$ & 0.000 \\
Maize & $\begin{array}{l}\text { Area Cultivated } \\
\text { Output } \\
\text { Area Cultivated } \\
\text { Sorghum }\end{array}$ & $0.839^{* *}$ & 0.000 \\
\hline$* *$ Output & $-0.182^{* *}$ & 0.000 \\
\hline Area Cultivated & 0.396
\end{tabular}

Table 4 presents the results of the correlation analysis between annual cropped area and output of each of the five selected crops. The analysis reveals the existence of very high positive correlations between area cropped area and output of four crops as follows: yam (0.978), rice $(0.886)$, cassava (0.839), maize (0.782) (all Ps<0.01). The significant levels of the four results being less than 0.01 indicating that there is sufficient evidence to support the assumption that the output of yam, cassava, rice, and maize crop in the study area is highly associated with annual expansion. However, a very weak negative correlation $(-.186, \mathrm{P}=0.396)$ is revealed for sorghum in the study area.

\section{Discussion}

The results of the correlation analysis, assessing the relationship between annual cropped area intensity and output of five selected crops in Benue state, namely: 
cassava, yam, sorghum, rice and maize (figures 4-8) showed a very high positive relationship for four of the crops (figures 4, 6, 7 and 8 respectively) but a very weak relationship for one crop (sorghum) see for example figure 5 above. This result revealed that as the annual area cultivated for cassava, yam, rice and maize crop increase in the study area, the output of the 4 crops also increase. Except for sorghum crop, where the result reveals an inverse relationship, indicating that as the annual area sown to sorghum crop increases, the output decreases and vice versa. The result of this study further shows that any attempt to reduce the rate of annual expansion of crop area will adversely affect the outputs of the four crops, with severe implications on the livelihood of farmers generally and their wellbeing in particular. Seeing that crop output (yield) in the area appears to be a function of the area sown to crops (see figures 4-8). This means that for farmers to sustain the current output of crops (cassava, yam, rice and maize) as well as meet the growing demand for food and so attain food security in state, the current trend in annual expansion of the area under cultivation for crops is likely going to keep increasing or at least be maintained, except for sorghum crop where reduction in the area under cultivation appears to have little or no relationship on output.

The trend in annual area expansion may be detrimental to the environment and other sectors such as industralisation, urban development and transportation (Epule et al., 2012; The Montpellier Panel, 2013). As more lands are being converted to crop area on annual basis, environmental challenges are likely to increase as well. For example, the rate of deforestation is likely to increase in the area, thus making the land susceptible to both land and soil erosion. The situation is also likely to exacerbate the impacts of desertification and climate change as massive release of $\mathrm{Co}_{2}$, high run-off and evapo-transpiration may be experienced in the area, far above the levels being presently experiencing in the area (Calzadilla et al., 2013; Epule et al., 2012).

Accordingly, reversing the trend in annual expansion of area under the cultivation is expected to be top on the policy agenda of the state. Boosting crops yield per unit area may be the grand strategy. Adoption of climate-smart agricultural (CSA) practices and technologies such as the use of high yielding seeds/genetically modified organisms (GMO), use of modern farm inputs, inorganic and organic fertilizers, herbicides and pesticides (Terdoo and Adekola, 2014; FAO, 2010). Others policies may focus on supporting and building capacity of farmers in the state to access farming inputs and loan facilities, designing and implementing programmes and projects aim at adding value to output of crops as well as increase farmers access to markets and tackling uncertainties in climate arising from reduced rainfall and increasing temperatures (Dawson et al., 2016; Grassini et al., 2013; Nin-Pratt and McBride, 2014). Also, they may be need for the state to development others sectors of the economy of the state (for example, the industrial and educational sectors) so as to reduce the population of people depending on agriculture as the main stay of their livelihoods. The latter is very important for diversification of the economy of the state. 
Annual Cropped Area Expansion and Agricultural Production................TERDO0 et al.

The result of this study, in a way, is consistent with the results of some related studies on the subjected matter carried out in other parts of Africa and the world. While in another way, the result is not consistent. For example, Rudel et al., (2009), assessed the relationship between agricultural intensification and changes in cultivated areas for the period of 19702005. The result reveals a lack of existing relationship $(\mathrm{r}=0.017, \mathrm{P}=0.606)$ between changes in yield and changes in cultivated areas across 961 agricultural sectors in 161 countries during the period under investigation. Similarly, in a study carried out by the Forum for Agricultural Reserach in Africa (2009) to investigate the patterns of change in maize production in Africa and to analysis the implications for maize policy development reveals that, the total production of maize in Africa had increased by about 17 million tons between 1986 and 2006 and that the acreage, productivity and interaction effects were all positive during the period. However, the acreage effect was $50 \%$ greater than the productivity $(39 \%)$ and interaction (14\%) effects respectively. For the overall period (1986 to 2006), the five sub-regions recorded positive effects in acreage, productivity and interaction, except for Southern Africa, where the acreage was negative as well as interaction effects for Central and Eastern Africa. The implication of the negative acreage effect for Southern Africa means a decline in the harvested area while the negative interaction effects for Central and Eastern African suggests a lack of relationship between acreage and productivity in the two regions during the period under review (Forum for Agricultural Reserach in Africa, 2009).

Furthermore, a study was carried out in Ghana to determine whether the improvement in some selected staple crops production in Ghana, namely: maize, millet, rice, sorghum, cassava, cocoyam, plantain and yam from 1999 to 2009 is due to area expansion or increased productivity (Akudugu et al., 2013). The result also revealed a positive relationship between output and area under cultivation. In addition, the result revealed that about 63 per cent of the growth in output of most of the staple crops in Ghana, in recent years is due largely to area expansion rather than improvements in productivity. Lastly, the situation was no different in Cameroon, a neighbouring country to Nigeria and Benue State in particular. In a study, (Epule et al., 2012), evaluated the interaction between forest area, $\mathrm{CO}_{2}$ emissions, rainfall and arable production at a national scale in Cameroon. The results reveal a relatively moderate positive relationship and /or correlation $(\mathrm{r}=0.668)$ between forest area and arable production per capita index. This result also indicated that the area under cultivation for crops is an important factor of agricultural intensification in the Africa in general and Benue State in particular. These results (Akudugu et al., 2013; Epule et al., 2012; Forum for Agricultural Reserach in Africa, 2009; Rudel et al., 2009), in a way, are very consistent with the result of this of the study.

Based on the results of the four studies presented above, it is clear that annual expansion of the area under the cultivation of crops has being an important variable in determining the 
output of crops in most African countries and other parts of the world, except in the developed countries where improvement in technology is a factor (Mandemaker et al., 2011). The situation is no different from the one being experienced in Benue State at the moment, where the output and/or productivity of most of the crops (maize, rice, cassava, and yam) is greatly influenced by the annual cropped area expansion as shown in the results of this study.

However, the situation is not the same for all crops. For example, in the case of sorghum crop, the study revealed a negative correlation $(-0.186, \mathrm{P}=0.396)$ implying that annual expansion of cropped area may not be a determining factor for sorghum output in the study area. While, it is not clear as to whether the improvement in sorghum cultivation may be responsible for the negative relationship between area cropped and sorghum output in the study area, the results of this study show that annual cropped area expansion for sorghum is beginning to decline or stagnate in most years while the output is increasing and vice versa. This is where the result of this study differs with the results of the four studies discussed above. Therefore the contribution of this study to the existing body of knowledge on the subject matter is that the study demonstrates that the output of sorghum crop in Benue State, Nigeria is not a function of annual crop area expansion. Also, the paper finds that annual sorghum output is increasing while the annual area expansion is decreasing in the study area. The study therefore emphasized the need for the crop production sub-sector sector of the agricultural sector of the state to formulate relevant policies to boost output per unit area rather than depending on the annual expansion of crop area to improve productivity.

\section{Conclusion}

Knowledge of whether the output of crops is a function of annual area expansion is key to developing relevant policies to reduce the area cultivated for crops and environmental consequences such as land degradation, soil erosion and deforestation that follow such practices in the present and future. Consequently, this study has investigated the relationship between annual area expansion for five selected crops in Benue state, namely, cassava, yam, rice, maize and sorghum. This study therefore concludes that there is a strong positive relationship between annual output and area expansion for cassava, yam, rice, and maize crops is Benue State. Thus upholding the assumption that annual output of crops in SSA and indeed the study area is a function of annual area expansion except for sorghum crop where a weak negative relationship exists between annual output and area expansion. To solve the problem of annual expansion of cropped area in the state, the study suggests the need for government policies to be directed toward improving productivity per unit area through sustainable agricultural intensification as this may significantly reduce the rate at which arable lands in the state are currently being converted to cropped area.

\section{References}

Akudugu, A.M., Garforth, C.J. and Dorward, P. (2013). Improvement in crop production in Ghana: Is it due to area expansion or increased 
productivity? Developing Country Studies, 3(1): 176-187.

Calzadilla, A., Zhu, T., Rehdanz, K., Tol, R.S.J. and Ringler, C. (2013). Economywide impacts of climate change on agriculture in SubSaharan Africa. Ecological Economics, 93: 150-165. doi:10.1016/j.ecolecon.2013.05.006

Dawson, N., Martin, A. and Sikor, T. (2016). Green Revolution in SubSaharan Africa: Implications of Imposed Innovation for the Wellbeing of Rural Smallholders. World Development, 78: 204-218. doi:10.1016/j.worlddev.2015.10.00 8

Epule, E.T., Peng, C., Lepage, L., Chen, Z. and Nguh, B.S. (2012). The Environmental Quadrupole: Forest Area , Rainfall , CO 2 Emissions and Arable Production Interactions in Cameroon. British Journal of Environment \& Climate Change, 2(1): 12-27.

FAO. (2010). "Climate-smart" agriculture: Policies, practices and financing for food security, adaptation and mitigation. Rome, Italy: Viale delle Terme di Caracalla.

Forum for Agricultural Reserach in Africa. (2009). Patterns of Change in Maize Production in Africa: Implications for Maize Policy Development. Ministerial Policy Brief Series. Networking Support Function 3: Regional Policies \& Markets, (3): 1-8. Retrieved from http://www.fara-africa.org

Grassini, P., Eskridge, K.M. and Cassman, K.G. (2013). Distinguishing between yield advances and yield plateaus in historical crop production trends. Nature Communications, 4: 2918. doi:10.1038/ncomms3918

Josephson, A. L., Ricker-Gilbert, J., \& Florax, R. J. G. M. (2014). How does population density influence agricultural intensification and productivity? Evidence from Ethiopia. Food Policy, 48: 142152.

doi:10.1016/j.foodpol.2014.03.004

Kassie, M., Teklewold, H., Jaleta, M., Marenya, P. and Erenstein, O. (2015). Understanding the adoption of a portfolio of sustainable intensification practices in eastern and southern Africa. Land Use Policy, 42: 400-411. doi:10.1016/j.landusepol.2014.08.0 16

Mandemaker, M., Bakker, M. and Stoorvogel, J. (2011). The Role of Governance in Agricultural Expansion and Intensification: a Global Study of Arable Agriculture. Ecology And Society, 16(2): 8. doi:10.5751/ES-04142-160208

National Bureau of Statistics (2012). Annual Abstract of Statistic. Federal republic of Nigeria

Nin-Pratt, A. and McBride, L. (2014). Agricultural intensification in Ghana: Evaluating the optimist's case for a Green Revolution. Food Policy, 48: 153-167. doi:10.1016/j.foodpol.2014.05.004

Phalan, B., Bertzky, M., Butchart, S.H.M., Donald, P.F., Scharlemann, J.P.W., Stattersfield, A.J. and Balmford, A. (2013). Crop expansion and conservation priorities in tropical countries. PloS One, $8(1)$ : e51759. doi:10.1371/journal.pone.0051759 
Pretty, J., Sutherland, W. J., Ashby, J., Auburn, J., Baulcombe, D., Bell, M., ... Pilgrim, S. (2010). The top 100 questions of importance to the future of global agriculture. International Journal of Agricultural Sustainability, 8(4): 219-236. doi:10.3763/ijas.2010.0534

Rudel, T.K., Schneider, L., Uriarte, M., Turner, B.L., DeFries, R.S., Lawrence, D., ... Grau, R. (2009). Agricultural intensification and changes in cultivated areas, 19702005. Proceedings of the National Academy of Sciences of the United States of America, 106(49): 2067580. doi:10.1073/pnas.0812540106

Saeed, K. (2000). Agricultural Land Use and Food Security in Asia: Green Revolution and Beyond. Worcester.
Sitko, N.J. and Jayne, T.S. (2014). Structural transformation or elite land capture? The growth of "emergent" farmers in Zambia. Food Policy, 48: 194-202. doi:10.1016/j.foodpol.2014.05.006

Terdoo, F. and Adekola. O. (2014). Assessing the role of climate-smart agriculture in combating climate change, desertification and improving rural livelihood in Northern Nigeria. African Journal of Agricultural Research, 9(15): 1180-1191. doi:10.5897/AJAR2013.7665

The Montpellier Panel. (2013). Sustainable Intensification: A New Paradigm for African Agriculture. London. 